\title{
The Effects of Different Passive Static Stretching Intensities on Recovery from Unaccustomed Eccentric Exercise - A Randomized Controlled Trial
}

\begin{tabular}{|c|c|}
\hline Journal: & Applied Physiology, Nutrition, and Metabolism \\
\hline Manuscript ID & apnm-2017-0841.R1 \\
\hline Manuscript Type: & Article \\
\hline Date Submitted by the Author: & 05-Feb-2018 \\
\hline Complete List of Authors: & $\begin{array}{l}\text { Apostolopoulos, Nikos; University of Toronto, Faculty of Kinesiology and } \\
\text { Physical Education } \\
\text { Lahart, Ian; University of Wolverhampton, } \\
\text { Plyley, Michael; Brock University, Faculty of Applied Health and Science } \\
\text { Taunton, Jack; University of British Columbia, Division of Sports Medicine, } \\
\text { Faculty of Medicine } \\
\text { Nevill, Alan; University of Wolverhampton } \\
\text { Koutedakis, Yiannis; University of Wolverhampton Faculty of Education } \\
\text { Health and Wellbeing; Univeristy of Thessaly } \\
\text { Wyon, Matthew; University of Wolverhampton, Research Centre for Sport } \\
\text { Exercise and Performance; National Institute of Dance Medicine } \\
\text { Metsios, George; University of Wolverhampton, Research Centre for Sport } \\
\text { Exercise and Performance }\end{array}$ \\
\hline Keyword: & DOMS, muscle function, performance \\
\hline $\begin{array}{r}\text { Is the invited manuscript for } \\
\text { consideration in a Special } \\
\text { Issue? : }\end{array}$ & N/A \\
\hline
\end{tabular}




\section{The Effects of Different Passive Static Stretching Intensities on Recovery from Unaccustomed Eccentric Exercise - A Randomized Controlled Trial}

Submission type: Original investigation

Nikos C. Apostolopoulos' ${ }^{1}$, Ian M. Lahart ${ }^{2}$, Michael J. Plyley ${ }^{3}$, Jack Taunton ${ }^{4}$, Alan M. Nevill ${ }^{2}$, Yiannis Koutedakis ${ }^{2,5}$, Matthew Wyon ${ }^{2,6}$, George S. Metsios ${ }^{2}$

1. Faculty of Kinesiology and Physical Education, University of Toronto, CA

2. Research Centre for Sport Exercise and Performance, Institute of Sport and Human Science, University of Wolverhampton, UK

3. Faculty of Applied Health Sciences, Brock University, CA

4. Division of Sports Medicine, Faculty of Medicine, University of British Columbia, CA

5. Department of Exercise Sciences, University of Thessaly, Trikala, GR

6. National Institute of Dance Medicine and Science, London, UK

\section{Corresponding Author:}

Nikos C. Apostolopoulos (corresponding author)

Faculty of Kinesiology and Physical Education,

University of Toronto, 55 Harbord St. Toronto, Ontario, M5S 2W6

Phone: +604 3458276

Email: nikos.apostolopoulos@utoronto.ca 


\section{ABSTRACT}

Effects of passive static stretching intensity on recovery from unaccustomed eccentric exercise of right knee extensors was investigated in 30 recreationally active males randomly allocated into three groups: high-intensity $(70-80 \%$ maximum perceived stretch), low-intensity (30-40\% maximum perceived stretch), and control. Both stretching groups performed 3 sets of passive static stretching exercises of 60 s each for hamstrings, hip flexors, and quadriceps, over 3 consecutive days, post-unaccustomed eccentric exercise. Muscle function (eccentric and isometric peak torque) and blood biomarkers (CK and CRP) were measured before (baseline) and after $(24,48$, and $72 \mathrm{~h})$ unaccustomed eccentric exercise. Perceived muscle soreness scores were collected immediately (time 0 ), and after 24,48 , and $72 \mathrm{~h}$ post-exercise. Statistical time $\mathrm{x}$ condition interactions observed only for eccentric peak torque $(p=.008)$. Magnitudebased inference analyses revealed low-intensity stretching had most likely, very likely, or likely beneficial effects on perceived muscle soreness $(48-72 \mathrm{~h}$ and $0-72 \mathrm{~h})$ and eccentric peak torque (baseline-24h and baseline-72h), compared with high-intensity stretching. Compared with control, low-intensity stretching had very likely or likely beneficial effects on perceived muscle soreness $(0-24 h$ and $0-72 h)$, eccentric peak torque (baseline-48h and baseline-72h), and isometric peak torque (baseline-72h). High-intensity stretching had likely beneficial effects on eccentric peak torque (baseline48h), but likely harmful effects eccentric peak torque (baseline-24h) and CK (baseline48h and baseline-72h), compared with control. Therefore, low-intensity stretching is likely to result in small-to-moderate beneficial effects on perceived muscle soreness and 
recovery of muscle function post-unaccustomed eccentric exercise, but not markers of muscle damage and inflammation, compared with high-intensity or no stretching.

Key Words: DOMS, performance, muscle function

\section{INTRODUCTION}

Delayed onset muscle soreness (DOMS) refers to the sensation of muscular discomfort and pain in response to eccentric muscle contractions, as well as to unaccustomed exercise, or high-intensity exercise (Paschalis et al., 2007b, Kanda et al., 2013). The intensity of discomfort associated with DOMS increases within the first $24 \mathrm{~h}$ postexercise, peaking between 24 and $72 \mathrm{~h}$, before disappearing 5-7 days post-exercise (Talag, 1973, Armstrong, 1984). The perception of soreness is suggested to be due to the activation of free nerve endings around muscle fibers serving as receptors of noxious stimuli associated with muscle damage (Byrnes and Clarkson, 1986).

In athletic performance, DOMS may have negative consequences, as the muscle soreness associated with DOMS may be responsible for temporarily restricting an individual's ability to perform an activity (Vasudevan, 1993). DOMS has been associated - inter alia - with a loss of maximum voluntary force (Newham et al., 1983, Newham et al., 1987, Clarkson et al., 1992), changes in the muscle contractile properties (Newham et al., 1983), increased protein levels related to muscle damage [i.e., creatine kinase (CK)] (Newham et al., 1987, Clarkson et al., 1992, Nosaka and Clarkson, 1992, Peake et al., 2005a), and decreased running economy (Paschalis et al., 2005). Since soreness associated with DOMS affects athletic performance, a strategy introduced to diminish the severity of DOMS sooner, may aid in the restoration of 
maximal function of muscle (Cheung et al., 2003). For non-athletes, early alleviation from the symptoms associated with DOMS post-exercise may increase adherence to regular exercise (Smith et al., 1994).

The proposed underlying mechanism for DOMS is acute inflammation (Smith, 1991), which may be influenced by the extent of, and response to, the muscle damage (Tidball, 2005). Therefore, actions that alleviate the damage and/or hasten the recovery (i.e., diminish the magnitude of the inflammatory response) would enhance recovery.

Muscular actions, such as unaccustomed eccentric muscle exercise of sufficient intensity and duration, have been repeatedly verified in human and animal studies as being responsible for the disruption of contractile and/or connective tissue (Friden et al., 1983, Lieber and Friden, 1993, Smith et al., 1994). DOMS activated in response to tissue injury, may be a form of acute inflammation and the sensation of soreness may represent inflammatory pain (Smith, 1991, Lieber and Friden, 1993, Maclntyre et al., 1995). The disruption of the muscle tissue is caused by an initial mechanical, and a secondary biochemical injury (Armstrong, 1984, Faulkner et al., 1993). The former is associated with a disorganization of the myofibrillar material, in particular, a focal disruption of the sarcomeres. Friden and Lieber (2001) suggest that the Z-disc is the most vulnerable structure to unaccustomed eccentric exercise induced injury. The biochemical injury is characterized by a 'local reaction' at the site of the damage, and results in the accumulation of neutrophils and macrophages, with the magnitude of the response related to both the intensity and duration of the exercise (Tiidus and lanuzzo, 1983, Castell et al., 1989, Robson et al., 1999, Peake, 2002, Peake et al., 2005a). Neutrophils appear within hours after exercise and remain for up to $48 \mathrm{~h}$ in human 
skeletal muscle (Malm et al., 2000, Frenette et al., 2000, Macintyre et al., 2000, Stupka et al., 2001, Beaton et al., 2002b), while macrophages appear at $24 \mathrm{~h}$ and remain present for up to 14 days (Malm et al., 2000, Beaton et al., 2002a, Beaton et al., 2002b, Peake et al., 2005a). The neutrophils and macrophages release a number of proinflammatory cytokines (Castell et al., 1989), including interleukin-1 $\beta$, tumor necrosis factor- $\alpha$, and interleukin-6. Intrerleukin- 6 is associated with an increased expression of C-reactive protein (CRP) (Castell et al., 1988, Bauer et al., 1989, Castell et al., 1989, Kushner and Rzewnicki, 1994). The rate of the increase in CRP concentration can be as high as 1000 -fold in response to muscle injury, and is used as a marker for injury (Volanakis and Narkates, 1981, Kushner, 1982, Gotschlich, 1989). Attempts have been made to identify a treatment for DOMS, including the use of non-steroidal antiinflammatory drugs (Janssen et al., 1983, Hasson et al., 1993, Hertel, 1997), massage (Weber et al., 1994, Lightfoot et al., 1997), cryotherapy (Gullick and Kimura, 1996), physical activity (Hasson et al., 1989), and stretching (High et al., 1989, Wessel and Wan, 1994, Lund et al., 1998, Johansson et al., 1999).

Investigations on stretching as a treatment modality for DOMS have focused on whether stretching can prevent or alleviate DOMS (High et al., 1989, Wessel and Wan, 1994, Lund et al., 1998, Johansson et al., 1999). Studies investigating the effects of preexercise static stretching on DOMS found no preventative effect on muscular soreness, tenderness, and force loss following unaccustomed eccentric exercise (High et al., 1989, Johansson et al., 1999). In addition, Lund et al. (1998) reported that passive static stretching following eccentric exercise had no significant effect on DOMS, CK, or dynamic muscle strength. Similarly, a systematic review, based on eligible randomized 
controlled trials, concluded that regardless of when stretching is performed, there were no clinically important reductions in DOMS (Herbert et al., 2011). However, none of these studies considered the effect of stretching intensity.

Therefore, the objective of the present study was to investigate the effects of low- and high-intensity passive static stretching compared to no stretching (control). The primary aim was to investigate the effects on perceived muscle soreness associated with unaccustomed eccentric exercise of the right knee extensors. Our secondary aim was to examine the effects on muscle function (eccentric and isometric peak torque) and blood biomarkers [CK and high sensitivity CRP (hsCRP)]. We hypothesized that lowintensity passive static stretching rendered over three consecutive days would lower perceived muscle soreness and blood biomarker concentrations and improve muscle function compared to high-intensity passive static stretching and no stretching.

\section{METHODS}

\section{Participants}

Institutional ethical approval was granted by the University of Wolverhampton. Thirty recreationally active males (age: $25 \pm 6$ y, mass: $83.1 \pm 10.7 \mathrm{~kg}$, height: $1.78 \pm 0.68 \mathrm{~m}$ ) were recruited. All participants were actively involved in resistance training on a regular basis, and were familiar with the concept of performing maximal contractions. Each participant read and signed the informed consent form, answered a physical activity readiness questionnaire (PARQ), and completed a blood analysis screening form prior to the investigation, looking for factors that may influence the investigation (e.g., alcohol, coffee, medication, smoking, activity levels). Additional exclusion criteria included any form of physical limitations regarding hips, knees, and ankles. Following the 
unaccustomed eccentric exercise, participants were advised to refrain from any physical activity, not consume alcohol, coffee, medication, and abstain from smoking, and to ensure that they get a good night's sleep for the duration of the study.

\section{Experimental Design and Procedures}

The 30 participants were randomly allocated, using an online randomization program (www.graphpad.com), into one of three groups: (i) low-intensity passive static stretching (30-40\% of maximum perceived stretch), (ii) high-intensity passive static stretching (70$80 \%$ of maximum perceived stretch), or (iii) no stretching (control), consisting of 10 participants per group. There were no withdrawals from the investigation.

The working definition of a "maximum perceived stretch" for this study refers to the individual's perception associated with pain and discomfort during passive static stretching. To measure maximum perceived passive static stretching, a numerical rating scale was referenced, with an anchor at 0 (i.e., no pain) and ranging to 10 (extreme pain). 'Maximum perceived' passive static stretching was equivalent to a value of 10 on this scale. On arrival, participants' anthropometric measurements [mass $(\mathrm{kg})$ and height $(\mathrm{m})]$ were taken. Figure 1 highlights the experimental process

\section{Pre-Unaccustomed Eccentric Exercise Assessment}

All participants were assessed at baseline (time 0 ), and at 24,48 , and $72 \mathrm{~h}$ preunaccustomed eccentric exercise, for eccentric and isometric peak torque of the right knee extensors on a KinCom isokinetic dynamometer (KinCom, www.kincom.com, East Ridge, Tennessee, USA). Muscle soreness/DOMS were assessed immediately 
following the unaccustomed eccentric exercise, and again at 24,48 , and $72 \mathrm{~h}$ postexercise, prior to each eccentric and isometric peak torque test.

Alignment of the rotational axis of the dynamometer and the right knee joint rotational axis (lateral femoral epicondyle) was set for each participant, with the ankle cuff being attached proximal to the lateral malleolus. In addition, each participant's upper body and left quadriceps was securely fastened before assessment. Familiarization consisted of 5 submaximal repetitions for each condition, with participants requested to apply $50 \%$ of maximal effort. This was immediately followed by a 1-min rest prior to the maximal effort for both eccentric and isometric peak torque. Eccentric peak torque was measured at $1.05 \mathrm{rad} / \mathrm{s}$ (i.e., $60^{\circ}$ per second), with the leg being moved through a range of motion starting at $20^{\circ}$ and progressing to $100^{\circ}$ of knee flexion. Isometric peak torque of the right knee flexion muscles was measured with the participant's knee being held at $60^{\circ}$ of knee flexion. To ensure standardization for the procedure for each participant, the force output was closely monitored on the KinCom display by an assistant. During the three maximal efforts, verbal encouragement was provided to each participant by the assistant, not part of the study, to eliminate bias, with the highest value being recorded (often the third attempt).

\section{Eccentric Exercise Protocol}

Following a 5-min rest period after the assessment for both eccentric and isometric peak torque, participants were familiarized and exposed to the eccentric exercise protocol for the right knee extensors. This protocol consisted of 6 sets of 10 eccentric repetitions through a range of motion from $20^{\circ}$ to $100^{\circ}$ of knee flexion at a speed of 1.05 $\mathrm{rad} / \mathrm{s}$, with a 2-min rest between sets, as previously described (Paschalis et al., 2007a). 
The familiarization process consisted of a single set of 10 submaximal repetitions using an identical setup as that for the unaccustomed eccentric exercise protocol. After a 1min rest, participants began the eccentric exercise protocol. To ensure standardization for the procedure for each participant of each group, the force output was closely monitored on the KinCom display by an assistant. Verbal encouragement was provided to each participant by the assistant not associated with the study to minimize bias.

Upon completion, participants were asked to rate their perceived muscle soreness on a numerical rating scale anchored at 0 (i.e., no soreness) to 10 (i.e., extremely sore), by palpating the distal region of the relaxed right knee extensors while seated. Participants returned to the laboratory at 24,48 , and $72 \mathrm{~h}$ following the unaccustomed eccentric exercise for both the eccentric and isometric peak torque tests, and the recording of their perceived muscle soreness levels prior to the muscle function tests for both eccentric and isometric peak torque.

\section{Stretching Exercise Protocol}

Following the unaccustomed eccentric exercise protocol, participants in both the lowintensity and high-intensity stretching groups performed an identical passive static stretching protocol bilaterally, for the hamstrings, hip flexors, and quadriceps muscle groups (in that order) for 3 consecutive nights prior to sleep (Figure 2). Although only the knee extensor muscle group was exposed to the unaccustomed eccentric exercise, this group has an antagonistic relationship to the hamstring muscle group, with both groups being influenced by the amount of hip flexion (Worrel et al., 1989).

During their first day at the laboratory, each participant was given one-on-one instruction on the proper form and execution of the three passive static stretching 
exercises to be performed at home before sleep, by a trained therapist, for three consecutive days. Using a numerical rating scale (anchored at 0 - no pain, to 10 extreme pain), participants for both stretching groups performed a maximum stretch to the point of extreme pain. Based on this perceived sensation, and scores on the numerical rating scale, the low-intensity stretching group was taught to maintain an intensity level of 3-4 out of 10 (i.e., a warm gentle feeling), with the high-intensity stretching group maintaining an intensity level of a 7-8 out of 10 (i.e., discomfort/slight pain). To reinforce the instructions given, a booklet with how to perform the exercises was provided. In addition, during the subsequent visits to the laboratory for the eccentric and isometric peak torque tests at 24 and $48 \mathrm{~h}$, participants were questioned about their respective stretching protocol by the therapist, particularly if they had been able to maintain the required stretching intensity level assigned to them.

Each stretch was supported with the use of a bench or pillow, allowing for better isolation and targeting of the muscle group of interest. Supporting the muscle minimizes muscular contraction from occurring during the stretch (Abdel-aziem et al., 2013). The duration of each passive static stretch was 60 s, and each was performed 3 times per muscle group per side (i.e., a total of 6-min per stretch), and the complete stretching routine lasted approximately $18-\mathrm{min}$.

\section{Statistical Analyses}

To correct violations of the assumption of normality detected via Shapiro-Wilk tests, CK and hsCRP were log transformed using natural logs (LN). We employed a GreenhouseGeisser correction to produce the F-ratio for perceived muscle soreness, hsCRP, and isometric peak torque due to significant Mauchly's Test of Sphericity. All other 
assumptions of mixed ANOVA were met (i.e., no significant outliers and non-significant Levene's tests for homogeneity of variances).

A two-way ANOVA with repeated measures for time $(0,24,48$, and $72 \mathrm{~h})$ and condition (low- and high-intensity stretching, and control) was performed on the variables for muscle function (eccentric and isometric peak torque) and perceived muscle soreness. Post hoc t-tests with Bonferoni adjustment for multiple comparisons were performed when significant main effects of time were detected. The level of statistical significance was set at $p<.05$. All statistical analyses were performed via SPSS software (version 20.0).

To detect small effects of practical performance, the data for the three conditions were analyzed using a contemporary magnitude-based inference approach (Hopkins, 2007). Each outcome was analysed via a spreadsheet (Hopkins, 2006) that used log transformation to estimate the effect of the conditions (low-intensity passive static stretching vs. high-intensity passive static stretching, low-intensity passive static stretching vs. control, and high-intensity passive static stretching vs. control) across each $24 \mathrm{~h}$ period [before, or immediately after, unaccustomed eccentric exercise (for perceived muscle soreness to $24 \mathrm{~h}, 24 \mathrm{~h}$ to $48 \mathrm{~h}$, and $48 \mathrm{~h}$ to $72 \mathrm{~h}$ )] as the difference in the mean percentage change, as well as in Cohen $d$ units. The thresholds for small, moderate, large, and very large effects (Cohen $d$ ) were 0.2, 0.6, 1.2, and 2.0 (Batterham and Hopkins, 2005). To estimate the chances that the stretching interventions had a beneficial, trivial or harmful effect, a Cohen unit of 0.2 was employed as the smallest meaningful effect on the dependent variables. Where the chance of benefit and harm are both $>5 \%$, the effect was deemed unclear. Qualitative descriptors were then 
assigned to quantitative percentile scores as follows: $25-75 \%$ possible, $75-95 \%$ likely, and $>99 \%$ most likely (Batterham and Hopkins, 2005, Hopkins, 2002, Hopkins, 2006). For comparisons that were not unclear, we reported the effect (i.e., beneficial, trivial, or harmful) with the highest \%. For each analysis the effect was adjusted for the outcome's baseline grand mean.

\section{RESULTS}

\section{Perceived Muscle Soreness}

No statistical difference was detected for a time $x$ condition interaction $(p=.573)$. However, a statistically significant main effect of time on perceived muscle soreness values after an unaccustomed eccentric exercise bout was observed $(p<.001)$, suggesting a reduction in perceived muscle soreness values over time regardless of condition (Table 1, Figure 3).

\section{Magnitude-based inference approach}

Low-intensity passive static stretching vs. high-intensity passive static stretching

The results of the magnitude-based inference analysis are presented in Tables $2-4$. Assuming that a small effect is meaningful (i.e., Cohen's $d=0.2$ ), low-intensity passive static stretching resulted in a likely small beneficial reduction in perceived muscle soreness immediately following unaccustomed eccentric exercise (time 0 ) to $24 \mathrm{~h}$, an unclear effect between $24-48 \mathrm{~h}$, and a likely moderate beneficial reduction in muscle soreness compared with high-intensity passive static stretching between $48-72 \mathrm{~h}$. However, low- versus high-intensity passive static stretching most likely had a large 
beneficial effect on perceived muscle soreness when time 0 was compared with $72 \mathrm{~h}$ (see Table 2).

Low-intensity passive static stretching vs. control

Low-intensity passive static stretching resulted in likely small and very likely large beneficial decrease in perceived muscle soreness from immediately post-unaccustomed eccentric exercise to $24 \mathrm{~h}$ and $72 \mathrm{~h}$ after, respectively. The effects of low intensity passive static stretching compared with control at subsequent timepoints were unclear (see Table 3).

High-intensity passive static stretching vs. control

The effect of high-intensity passive static stretching versus control on perceived muscle soreness was unclear between all assessment timepoints (see Table 4).

\section{Eccentric Peak Torque}

A statistically significant main effect for time on eccentric peak torque scores $(p<.001)$ was observed, indicating that scores differ across timepoints. The time $\mathrm{x}$ condition interaction effect was significant $(p=.008)$, indicating that eccentric peak torque scores differed across assessment timepoints for the three conditions. Simple main effects analysis revealed that all three conditions statistically changed over time (high-intensity, $p=.001$; low-intensity, $p=.024$; control, $p=.014$ ), whereas statistically significant between-group differences were observed at $48 h(p=.017)$ and $72 h(p=.019)$, but not at baseline $(p=.399)$ or $24 \mathrm{~h}(p=.061)$. As shown in figure 4 , eccentric peak torque decreased from baseline to $24 \mathrm{~h}$ post-eccentric exercise in all groups, but over the 
subsequent $48 \mathrm{~h}$ period, only the low-intensity passive static stretching group increased consistently (Table 1, Figure 4).

\section{Magnitude-based inference approach}

Low-intensity passive static stretching vs. high-intensity passive static stretching

Compared with high-intensity passive static stretching, low-intensity passive static stretching had a very likely moderate beneficial effect on eccentric peak torque from baseline to $24 \mathrm{~h}$ and $72 \mathrm{~h}$ following an unaccustomed eccentric exercise. The effect from baseline to $48 \mathrm{~h}$ was possibly small beneficial effect (see Table 2).

Low-intensity passive static stretching vs. control

Compared with the control condition, low-intensity passive static stretching had a very likely moderate and likely small beneficial effect on eccentric peak torque from baseline to 48 and $72 \mathrm{~h}$, respectively. The effect from baseline to $24 \mathrm{~h}$ was unclear (see Table 3 ).

High-intensity passive static stretching vs. control

From baseline to $24 \mathrm{~h}$ post-unaccustomed eccentric exercise, high-intensity passive static stretching had a likely small harmful effect on eccentric peak torque, but a likely moderate beneficial effect from baseline to $48 \mathrm{~h}$, compared with control. The effect from baseline to $72 \mathrm{~h}$ was unclear (see Table 4).

Isometric Peak Torque 
Although no significant difference was observed between time $x$ condition interaction ( $p$ $=.185)($ Table 2$)$, a significant main effect of time $(p<.001)$ was observed. Post hoc tests showed that values were lower at $24 \mathrm{~h}$ compared with baseline $(p<.001)$, higher at $48 \mathrm{~h}$ compared with $24 \mathrm{~h}(\mathrm{p}=.036)$, and at $72 \mathrm{~h}$ compared with both $24 \mathrm{~h}(\mathrm{p}<.001)$ and $48 \mathrm{~h}(\mathrm{p}=$ $.014)$, compared with $24 \mathrm{~h}(\mathrm{p}<.01)$ (Table 1, Figure 5).

\section{Magnitude-based inference approach}

Low-intensity passive static stretching vs. high intensity passive static stretching

The effect of low-intensity passive static stretching compared with high-intensity passive static stretching was trivial from baseline to $24 \mathrm{~h}$, possibly small (beneficial) from baseline to $48 \mathrm{~h}$, and unclear from baseline to $72 \mathrm{~h}$ post-unaccustomed eccentric exercise (see Table 2).

Low-intensity passive static stretching vs. control

Compared with control, low-intensity passive static stretching resulted in possibly and likely small beneficial effects on isometric peak torque from baseline to 48 and $72 \mathrm{~h}$, respectively. From baseline to $24 \mathrm{~h}$ the effects were unclear (see Table 3).

High-intensity passive static stretching vs. control

The effects of high-intensity passive static stretching compared with control were unclear for comparisons between each timepoint compared with baseline (see Table 4).

\section{Creatine Kinase}

A statistically significant main effect was found for time on the CK (LN transformed) values $(p<.001)$. Post hoc tests revealed statistically lower creatine kinase values at 
baseline compared with $24 \mathrm{~h}(p<.001)$ and $48 \mathrm{~h}(\mathrm{p}=.010)$, and statistically higher at $24 \mathrm{~h}$ compared with 48 and $72 h(p=.049$ and .003$)$, respectively. There was no statistically significant interaction effect between time and condition $(p=.148)$ (Table 5, Figure 6).

\section{Magnitude-based inference approach}

Low-intensity passive static stretching vs. high-intensity passive static stretching

Compared with high-intensity passive static stretching and control, low-intensity passive static stretching possibly resulted in a small beneficial decrease in CK concentrations from baseline to $72 \mathrm{~h}$ post-unaccustomed eccentric exercise. The effects were unclear between the other timepoints (see Table 2).

Low-intensity passive static stretching vs. control

Low-intensity passive static stretching, compared with control, possibly resulted in a harmful small increase in CK concentration from baseline to $48 \mathrm{~h}$ after unaccustomed eccentric exercise. Effects between all other timepoints were unclear (see Table 3).

High-intensity passive static stretching vs. control

High-intensity passive static stretching likely resulted in small harmful increases in CK from baseline to 48 and $72 \mathrm{~h}$ post-unaccustomed eccentric exercise, compared with control. The effect from baseline to $24 \mathrm{~h}$ was unclear (see Table 4).

\section{High sensitivity C-Reactive Protein}

There was a statistically significant main effect of time on hsCRP (LN transformed) concentrations, $(p=.012)$. Bonferoni corrected post hoc tests showed that the hsCRP values were statistically higher at 24 versus $72 h(p=.012)$. However, there was no statistically significant time by condition interaction $(p=.588)$ (Table 5 , Figure 7$)$. 


\section{Magnitude-based inference approach}

Low-intensity passive static stretching vs. high-intensity passive static stretching

The magnitude-based inference approach indicated a likely small harmful effect of lowintensity passive static stretching on hsCRP concentrations assessed from baseline to 24h after eccentric exercise, when compared with high-intensity passive static stretching. Comparisons at the other timepoints were unclear (see Table 2).

Low-intensity passive static stretching vs. control

The effect of low-intensity passive static stretching compared with control on hsCRP was unclear for all assessment timepoint comparisons (see Table 3).

High-intensity stretching vs. control

High-intensity stretching compared with control had possibly a small harmful effect on hsCRP from baseline to $72 \mathrm{~h}$ after unaccustomed eccentric exercise. The effect of highintensity passive static stretching at the other timepoints was unclear (see Table 4).

\section{DISCUSSION}

To our knowledge this is the first study that investigated in a randomised design, the effects of different passive static stretching intensities following an unaccustomed eccentric exercise on perceived muscle soreness, muscular function, and biomarkers related to muscle damage and inflammation. Our results suggest that low-intensity passive static stretching may lower perceived muscle soreness and improve eccentric peak torque recovery to a greater extent compared with high-intensity passive static stretching and control, $72 \mathrm{~h}$ post-unaccustomed eccentric exercise. The remaining results, including our biomarkers and the comparisons between control and high- 
intensity passive static stretching conditions, revealed mainly small, trivial, or unclear effects, and thus, their interpretation should be treated with caution.

Studies on stretching and DOMS following unaccustomed eccentric exercise have investigated the timing of stretching (i.e., before, after, or before and after exercise), and whether stretching produces reductions in muscle soreness (High et al., 1989, Wessel and Wan, 1994, Lund et al., 1998, Johansson et al., 1999, Gulick et al., 1996, Herbert et al., 2011). To our knowledge, only Smith et al. (1993) investigated the effects of stretching on the induction of DOMS. They evaluated a bout of static versus ballistic stretching of similar intensity and duration on the induction of DOMS over a 5 day period. Their study revealed that static stretching was responsible for inducing significantly more DOMS than ballistic stretching. Our study adds to the body of knowledge in this field, suggesting that low-intensity passive static stretching (30-40\% of maximum) is at least very likely effective compared to the other two conditions in reducing perceived muscle soreness over $72 \mathrm{~h}$, possibly due to the difference in the magnitude of the stretch between the conditions. In line with our observations, Behm and Kibele (2007) suggest that stretches to a maximal point of discomfort, as well as submaximal stretching greater than $50 \%$ of point of discomfort, are responsible for muscle damage, similar to the effects seen with the eccentric-induced damage associated with DOMS. Another potential reason for these likely beneficial effects of low-intensity passive static stretching is the time that the stretching was held (i.e. 60 s). Our findings are in line with a study of individuals aged 65 years or greater, where low intensity stretching held for 60s was found to be more effective for increasing knee extension ROM compared to 30s, 15s or, control (Feland et al., 2001). In addition, a 
clear dose-response effect for stretch duration has been reported, suggesting that stretches held greater than 60s are more likely to impair performance (Kay and Blazevich, 2012). Therefore, despite the different participant samples utilized in these investigations and our study, taken collectively these observations may suggest that the time passive static stretching is held may have implications on perceived muscle soreness. Further research is required to elucidate these phenomena.

With regard to muscle function, several studies and systematic reviews have reported that stretching can induce a decrease in strength or power output for isolated muscle groups following an unaccustomed eccentric exercise (Kokkonen et al., 1998, Behm et al., 2001, Church et al., 2001, Nelson and Kokonnen, 2001, Young and Elliot, 2001, Cramer et al., 2004, Power et al., 2004, Cramer et al., 2005, Marek et al., 2005, Behm and Chaouachi, 2011, Kay and Blazevich, 2012, Behm et al., 2016). For instance, a systematic review highlighted a clear dose-response effect for stretch duration, with longer held acute static stretches $(\geq 60$ s) being more likely to elicit performance impairments compared to shorter duration stretching (<60s) (Kay and Blazevich, 2012). In line with this, a recent study by Behm et al. (2016) revealed that longer stretch durations may elicit performance impairments, which may have implications for athletic and clinical performance. Whereas some studies tested participants immediately after stretching (Marek et al., 2005, Kokkonen et al., 1998, Cramer et al., 2005), Haddad et al. (2014) retested explosive performance (long jump) and repeated sprint ability $24 \mathrm{~h}$ post-stretching, and concluded that static stretching continued to have a negative effect on performance. However, it is noteworthy that the available studies do not take into account the intensity of the stretching exercises. To investigate the potential role of 
stretching intensity, Behm and Kibele (2007) observed that to achieve maximum jump height, athletes should perform static stretching of an intensity less than $50 \%$ of point of discomfort prior to performance. In line with this finding, our data show that low-intensity passive static stretching resulted in small to moderate beneficial effects on eccentric peak torque compared to both high-intensity passive static stretching and control. Our findings for isometric peak torque were less consistent, with low-intensity passive static stretching resulting in beneficial effects over control (baseline-72h) but not high-intensity passive static stretching. However, the observed improvements in eccentric peak torque over the three consecutive days with low-intensity passive static stretching suggest an increased level of recovery, given that a decrease in maximal muscle torque is considered to be the best index of muscle damage (Paschalis et al., 2007b).

With regard to our biomarker data, $\mathrm{CK}$ is a biomarker associated with damage to skeletal muscle cell structure and can be altered via different exercise modalities (Brancaccio et al., 2007). Given the observation that CK was overall increased at 24 and $48 \mathrm{~h}$ post unaccustomed eccentric exercise, our results are in line with this notion. However, based on the overall small, trivial, or unclear effects observed, we suggest these observations need further investigation in appropriately designed trials. For our inflammatory biomarker, hsCRP, it is known that the extent of the inflammatory response can depend on the muscle groups used, the amount of muscle mass recruited during eccentric exercise (Peake et al., 2005b), and the exercise modality (Akimoto et al., 2002, Weight et al., 1991). Our data confirm these observations as hsCRP was statistically higher after $24 \mathrm{~h}$ of unaccustomed eccentric exercise compared to other timepoints. However, similar to $\mathrm{CK}$, the magnitude of the effects of low-intensity passive 
static stretching on CRP was mainly unclear when compared to other conditions and timepoints, thus there appeared to be no advantage for either stretching intensity versus control.

Despite the strengths of this study [e.g. randomisation, the quantification of the stretching intensity, and removing body position as a potential influence on the intensity of the stretch (Apostolopoulos et al., 2015)], this study has limitations. These limitations include the potential lack of sufficient statistical power to detect differences between conditions for outcomes, the absence of data from the isokinetic dynamometry for the quantification of the unaccustomed eccentric exercise through a reduction in force output from the first to the sixth set, the unsupervised nature of the passive static stretching interventions, and the lack of blinding of the assessor to the study's assessments.

\section{Conclusion}

Compared to high-intensity passive static stretching and no stretching, low-intensity passive static stretching results in small-to-moderate beneficial effects on perceived muscle soreness and recovery of muscle function post-unaccustomed eccentric exercise. Since soreness associated with DOMS affects athletic performance, a decrease in perceived muscle soreness may aid in the restoration of maximal muscle function, and an increased adherence to regular exercise with non-athletes. Future studies should employ larger populations, use supervised stretching, and assess both indirect measures (eccentric and isometric peak torque, CK, hsCRP, inflammatory cytokines, and subjective soreness responses) and direct measures, such as 
examination of muscle samples, to determine muscle damage following unaccustomed eccentric exercise.

\section{Conflict of Interest}

The authors have no conflict of interest to report

\section{REFERENCES}

ABDEL-AZIEM, A. A., DRAZ, A. H., MOSAAD, D. M. \& ABDELRAOU, O. R. 2013. Effect of body position and type of stretching on hamstring flexibility. Int. J. Med. Res. Health Sci., 2, 399-406.

AKIMOTO, T., FURUDATE, M., SAITOH, M., SUGIURA, K., WAKU, T., AKAMA, T. \& KONO, I. 2002. Increased plasma concentrations of intercellular adhesion molecule-1 after strenuous exercise associated with muscle damage. Eur. J. Appl. Physiol., 86, 185-190.

APOSTOLOPOULOS, N., METSIOS, G. S., FLOURIS, A. D., KOUTEDAKIS, Y. \& WYON, M. 2015. The relevance of stretch intensity and position - a systematic review. Front. Psychol., 6, 1128.

ARMSTRONG, R. B. 1984. Mechanisms of exercise-induced delayed onset muscular soreness: a brief review. Med. Sci. Sports Exerc., 16, 529-538.

BATTERHAM, A. M. \& HOPKINS, W. G. 2005. Making meaningful inferences about magnitudes. Sportscience, 2002, 6-13.

BAUER, J., LENGYEL, G., BAUER, T. M., ACS, G. \& GEROK, W. 1989. Regulation of interleukin-6 receptor expression in human monocytes and hepatocytes. FEB. Letters, 249, 27-30.

BEATON, L. J., ALLAN, D. A., TARNOPOLSKY, M. A., TIIDUS, P. \& PHILLIPS, D. R. 2002a. Contraction induced muscle damage is unaffected by vitamin $E$ supplementation. Med. Sci. Sports Exerc., 34, 798-805.

BEATON, L. J., TARNOPOLSKY, M. A. \& PHILLIPS, S. M. 2002b. Contraction-induced muscle damage in humans following calcium channel blocker administration. J. Physiol., 544, 849-859.

BEHM, D. G., BLAZEVICH, A. J., KAY, A. D. \& MCHUGH, M. 2016. Acute effects of muscle stretching on physical performance, range of moiton, and injury incidence in helathy active individuals: a systematic review. Appl. Physiol. Nutri. Metabol., 41, 1-11. 
BEHM, D. G., BUTTON, D. C. \& BUTT, J. C. 2001. Factors affecting force loss with prolonged stretching. Can. J. Appl. Physiol., 26, 261-272.

BEHM, D. G. \& CHAOUACHI, A. 2011. A review of the acute effects of static and dynamic stretching on performance. Eur. J. Appl. Physiol., 11, 2633-2651.

BEHM, D. G. \& KIBELE, A. 2007. Effects of differing intensities of static stretching on jump performance. Eur. J. Appl. Physiol., 101, 587-594.

BRANCACCIO, P., MAFFULLI, N. \& LIMONGELLI, F. M. 2007. Creatine kinase monitoring in sport medicine. Bri. Med. Bull., 81-82, 209-233.

BYRNES, W. C. \& CLARKSON, P. M. 1986. Delayed onset muscle soreness and training. Clin. Sports Med., 5, 605-614.

CASTELL, J. V., ANDUS, T., KUNZ, D. \& HEINRICH, P. C. 1989. Interleukin-6 the major regulator of acute-phase protein synthesis in man and rat. Ann. N.Y. Acad. Sci., 557, 87-101.

CASTELL, J. V., GOMEZ-LECHION, M. J., DAVID, M., HIRANO, T., KISHIMOTO, T. \& HEINRICH, P. C. 1988. Recombinant human interleukin-6 (IL-6/BSF-2/HSF) regulates the synthesis of acute phase proteins in human hepatocytes. FEB. Letters, 232, 347-350.

CHEUNG, K., HUME, P. \& MAXWELL, L. 2003. Delayed onset muscle soreness: treatment strategies and performance factors. Sports Med., 33, 145-164.

CHURCH, J. B., WIGGINS, M. S., MOODE, F. M. \& CRIST, R. 2001. Effect of warm-up and flexibility treatments on vertical jump performance. J. Strength Cond. Res., 15, 332-336.

CLARKSON, P. M., NOSAKA, K. \& BRAUN, B. 1992. Muscle function after exerciseinduced muscle damage and rapid adaptation. Med. Sci. Sports Exerc., 24, 512520.

CRAMER, J. T., HOUGH, T. J., JOHNSON, G. O., MILLER, J. M., COBURN, J. W. \& BECK, T. W. 2004. The effects of static stretching on peak torque in women. J. Strength Cond. Res., 18, 176-182.

CRAMER, J. T., HOUGH, T. J., WEIR, J. P., JOHNSON, G. O., COBURN, J. W. \& BECK, T. W. 2005. The acute effects of static stretching on peak torque, mean power output, electromyography, and mechanomyography. Eur. J. Appl. Physiol., 93, 540-539.

FAULKNER, R. A., BROOKS, S. V. \& OPITECK, J. A. 1993. Injury to skeletal muscle fibers during contractions: conditions of occurrence and prevention. Phys. Ther., 73, 911-921.

FELAND, J. B., MYRER, J. W., SCHULTHIES, S., FELLINGHAM, G. \& MEASOM, G. 2001. The effect of duration of stretching of the hamstring muscle group for increasing range of motion in people aged 65 years or older. Phys. Ther., 81, $1110-1117$.

FRENETTE, J., CAI, B. \& TIDBALL, J. G. 2000. Complement activation promotes muscle inflammation during modified muscle use. Am. J. Pathol., 156, 21032110.

FRIDEN, J. \& LIEBER, R. L. 2001. Eccentric exercise-induced injuries to contractile and cytoskeletal muscle fibre compnents. Acta. Physiol. Scand., 171, 321-326.

FRIDEN, J., SJOSTROM, M. \& EKBLOM, B. 1983. Myofibrillar damage following intense eccentric exercise in man. Int. J. Sports. Med., 4, 170-176. 
GOTSCHLICH, E. C. 1989. C-reactive protein a historical overview. Ann. N.Y. Acad. Sci., 557, 9-18.

GULICK, D. T., KIMURA, I. F., SITLER, M., PAOLONE, A. \& KELLY, J. D. 1996. Various treatment techniques on signs and symptoms of delayed onset muscle soreness. J. Athletic Train, 31, 145-152.

GULLICK, D. T. \& KIMURA, I. F. 1996. Delayed onset muscle soreness: what is it and how do we treat it? J. Sport Rehabil., 5, 234-243.

HASSON, S., BARNES, W., HUNTER, M. \& WILLIAMS, J. 1989. Therapeutic effects of high speed voluntary muscle contractions on muscle soreness and muscle performance. JOSPT, 10, 499-507.

HASSON, S. M., DANIELS, J. C., DIVINE, J. G., NIEBUHR, B. R., RICHMOND, S., STEIN, P. G. \& WILLIAMS, J. H. 1993. Effect of ibuprofen use on muscle soreness, damage, and performance: a preliminary investigation. Med. Sci. Sports Exerc., 25, 9-17.

HERBERT, R. D., DE NORONHA, M. \& KAMPER, S. J. 2011. Stretching to prevent or reduce muscle soreness after exercise. Cochrane Database Syst. Rev., 7, 1-47.

HERTEL, J. 1997. The role of nonsteroidal anti-inflammatory drugs in the treatment of acute soft tissue injuries. J. Athl. Training, 32, 350-358.

HIGH, D. M., HOWLEY, E. T. \& FRANKS, B. D. 1989. The effects of static stretching and warm-up on prevention of delayed onset muscle soreness. Res. Q. Exerc. Sport, 60, 357-361.

HOPKINS, W. G. 2002. Probabilities of clinical or practical significance. Sportscience, 6.

HOPKINS, W. G. 2006. Spreadsheets for analysis of controlled trials, with adjustment for a subject characteristic. Sportscience, 10, 46-50.

HOPKINS, W. G. 2007. A spreadsheet for deriving a confidence interval, mechanistic inference and clinical inference from a p value. Sportscience, 11, 16-20.

JANSSEN, E., KUIPERS, H., VERTSAPPEN, F. \& COSTILL, D. 1983. Influence of antiinflammatory drugs on muscle soreness. Med. Sci. Sports Exerc., 15, 165.

JOHANSSON, P. H., LINDSTROM, L., SUNDELIN, G. \& LINDSTROM, B. 1999. The effects of preexercise stretching on muscular soreness, tenderness and force loss following heavy eccentric exercise. Scand. J. Med. Sci. Sports, 9, 219-225.

KANDA, K., SUGAMA, K., HAYASHIDA, H., SAKUMA, J., KAWAKAMI, Y., MIURA, S., YOSHIOKA, H., MORI, Y. \& SUZUKI, K. 2013. Eccentric exercise-induced delayed-onset muscle soreness and changes in markers of muscle damage and inflammation. Exerc. Immunol. Rev., 19, 72-85.

KAY, A. D. \& BLAZEVICH, A. J. 2012. Effect of acute static stretch on maximal muscle performance: a systematic review. Med. Sci. Spors Exerc., 44, 154-164.

KOKKONEN, J., NELSON, A. G. \& CORNWELL, A. 1998. Acute muscle stretching inhibits maximal strength performance. Res. Q. Exer. Sport, 69, 411-415.

KUSHNER, I. 1982. The phenomenon of the acute phase response. Ann. N.Y. Acad. Sci., 389, 39-48.

KUSHNER, I. \& RZEWNICKI, D. L. 1994. The acute phase response: general aspects. Bailliere's Clin. Rheum., 8, 513-530.

LIEBER, R. L. \& FRIDEN, J. 1993. Muscle damage is not a function of muscle force but active muscle strain. J. Appl. Physiol., 74, 520-526. 
LIGHTFOOT, T. J., CHAR, D., MCDERMOTT, J. \& GOYA, C. 1997. Immediate post exercise massage does not attenuate delayed onset muscle soreness. $J$. Strength Cond. Res., 11, 119-124.

LUND, H., VESTERGAARD-POULSEN, P., KANSTRUP, I.-L. \& SEJRSEN, P. 1998. The effect of passive stretching on delayed onset muscle soreness, and other detrimental effects following eccentric exercise. Scand. J. Med. Sci. Sports, 8, 216-221.

MACINTYRE, D. L., REID, W. D., LYSTER, D. M. \& MCKENZIE, D. C. 2000. Different effects of strenuous eccentric exercise on the accumulation of neutrophils in muscle in women and men. Eur. J. Appl. Physiol., 81, 47-53.

MACINTYRE, D. L., REID, W. D. \& MCKENZIE, D. C. 1995. The inflammatory response to muscle injury and its clinical implications. Sports Med., 20, 24-40.

MALM, C., NYBERG, P., ENGSTROM, M., SJODIN, B., LENKEI, R. \& EKBLOM, B. 2000. Immunological changes in human skeletal muscle and blood after eccentric exercise and multiple biopsies. J. Physiol., 529, 243-262.

MAREK, S. M., CRAMER, J. T., FINCHER, A. L., MASSEY, L. L., DANGLEMEIER, S. M., PURKAYASTHA, S., FITZ, K. A. \& CULBERTSON, J. Y. 2005. Acute effects of static and proprioceptive neuromuscular facilitation on muscle strength and power output. J. Athl. Training, 40, 94-103.

NELSON, A. G. \& KOKONNEN, J. 2001. Acute ballistic muscle stretching inhibits maximal strength performance. Res. Q. Exer. Sport, 72, 415-419.

NEWHAM, D. J., JONES, D. A. \& CLARKSON, P. M. 1987. Repeated high-force eccentric exercise: effects on muscle and damage. J. Appl. Physiol., 63, 13811387.

NEWHAM, D. J., MILLS, K. R., QUIGLEY, B. M. \& EDWARDS, R. H. T. 1983. Pain and fatigue after concentric and eccentric contractions. Clin. Sci., 64, 55-62.

NOSAKA, K. \& CLARKSON, P. M. 1992. Relationship between post exercise plasma CK elevation and muscle mass involved in the exercise. Inter. J. Sports Med., 13, 471-475.

PASCHALIS, V., GIAKAS, G., BALTZOPOULOS, V., JAMURTAS, A. Z., THEOHARIS, V., KOTZAMANIDIS, C. \& KOUTEDAKIS, Y. 2007a. The effects of muscle damage following eccentric exercise on gait biomechanics. Gait \& Posture, 25, 236-242.

PASCHALIS, V., KOUTEDAKIS, Y., BALTZOPOULOS, V., MOUGIOS, V., JAMURTAS, A. Z. \& THEOHARIS, V. 2005. The effects of muscle damage on running economy in healthy males. Int. J. Sports Med., 26, 827-831.

PASCHALIS, V., NIKOLAIDIS, M. G., FATOUROS, I. G., GIAKAS, G., KOUTEDAKIS, Y., KARATZAFERI, C., KOURETAS, D. \& JAMURTAS, A. Z. 2007b. Uniform and prolonged changes in blood oxidative stress after muscle-damaging exercise. In vivo, 21, 877-883.

PEAKE, J. M. 2002. Exercise-induced alterations in neutrophil degranulation and respiratory burst activity: possible mechanisms of action. Exerc. Immunol. Rev., $8,49-100$.

PEAKE, J. M., NOSAKA, K. \& SUZUKI, K. 2005a. Characterization of inflammatory responses to eccentric exercise in humans. Exerc. Immunol. Rev., 11, 64-85. 
PEAKE, J. M., SUZUKI, K., WILSON, G., HORDERN, M., NOSAKA, K. \& MACINTYRE, D. L. 2005b. Exercise induced muscle damage, plasma cytokines and markers of neutrophil activation. Med. Sci. Sports Exerc., 37, 737-745.

POWER, K., BEHM, D., FARREL, C., CARROLL, M. \& YOUNG, W. 2004. An acute bout of static stretching: effects on force and jumping performance. Med. Sci. Sports Exerc., 36, 1389-1396.

ROBSON, P. J., BLANNIN, A. K., ALLAN, D. A., WALSH, N. P., CASTELL, L. M. \& GLEESON, M. 1999. Effects of exercise intensity, duration and recovery on in vitro neutrophil function in male athletes. Int. J. Sports Med., 20, 128-135.

SMITH, L. L. 1991. Acute inflammation: the underlying mechanism in delayed onset muscle sorenes? Med. Sci. Sports Exerc., 23, 542-551.

SMITH, L. L., BRUNETZ, M., CHENIER, T., MCCAMMON, M., HOUMARD, J., FRANKLIN, M. \& ISRAEL, R. 1993. The effects of static and ballistic stretching on delayed onset muscle soreness and creatine kinase. Res. Q. Exerc. Sport, 64, 103-107.

SMITH, L. L., KEATING, M. N., HOLBERT, D., SPRATT, D. J., MCCAMMON, M. R., SMITH, S. S. \& ISRAEL, R. G. 1994. The effects of athletic massage on delayed onset muscle sorenss, creatine kinased, and neutrophil count: a preliminary report. JOSPT, 19, 93-99.

STUPKA, N., TARNOPOLSKY, M. A., YARDLEY, N. J. \& PHILLIPS, S. M. 2001. Cellular adaptation to repeated eccentric exercise-induced muscle damage. $J$. Appl. Physiol., 91, 1669-1678.

TALAG, T. S. 1973. Residual muscular soreness as influenced by concentric, eccentric and static contractions. Res. Q. 44, 458-469.

TIDBALL, J. G. 2005. Inflammatory processes in muscle injury and repair. Am. J. Physiol. Regul. Integr. Comp. Physiol., 288, R345-R353.

TIIDUS, P. \& IANUZZO, C. 1983. Effects of intensity and duration of muscular exercise on delayed onset muscle soreness and serum enzymes activities. Med. Sci. Sports. Exerc., 15, 461-465.

VASUDEVAN, S. V. 1993. Impairment, disability and functional capacity assessment, New York, The Guildford Press.

VOLANAKIS, J. E. \& NARKATES, A. J. 1981. Interaction of C-reactive protein with artificial phosphatidyl choline bilayers and complement. J. Immunol., 126, 18201825.

WEBER, M. D., SERVEDIO, F. J. \& WOODALL, W. R. 1994. The effects of three modalities on delayed onset muscle soreness. J. Sports Phys. Ther., 20, 236242.

WEIGHT, L. M., ALEXANDER, D. \& JACOBS, P. 1991. Strenuous exercise: analogous to the acute-phase response? Clin. Sci. (Lond), 81, 677-683.

WESSEL, J. \& WAN, A. 1994. Effect of stretching on the intensity of delayed-onset muscle soreness. Clin. J. Sport Med., 4, 83-87.

WORREL, T. W., PERRIN, D. H. \& DENEGAR, C. R. 1989. The influence of hip position on quadriceps and hamstring peak torque and reciprocal muscle group ratio values. JOSPT, 11, 104-107.

YOUNG, W. \& ELLIOT, S. 2001. Acute effects of static stretching, proprioceptive neuromuscular facilitation stretching, and maximum voluntary contractions on 
explosive force production and jumping performance. Res. Q. Exer. Sport, 72, 273-279. 
TABLES FOR MANUSCRIPT-THE EFFECT OF DIFFERENT PASSIVE STATIC STRETCH INTENSITIES ON RECVOERY FROM UNACCUSTOMED ECCENTRIC EXERCISE -A RANDOMIZED CONTROLLED TRIAL

TABLE 1. Measurements of Perceived Muscle Soreness, Eccentric Peak Torque, and Isometric Peak Torque over 72 hours Post Unaccustomed Eccentric Exercise Protocol (Values are Mean \pm SD; $n=10$ per group).

\begin{tabular}{|c|c|c|c|c|c|c|c|c|c|c|c|c|}
\hline \multirow{2}{*}{ Condition } & \multicolumn{4}{|c|}{ Soreness } & \multicolumn{4}{|c|}{ Eccentric Peak Torque (Nm) } & \multicolumn{4}{|c|}{ Isometric Peak Torque (Nm) } \\
\hline & Oh & $24 h$ & $48 h$ & $72 h$ & Oh & $24 h$ & $48 h$ & $72 \mathrm{~h}$ & Oh & $24 h$ & $48 h$ & $72 \mathrm{~h}$ \\
\hline $\begin{array}{l}\text { Low-Intensity } \\
\text { Passive Static } \\
\text { Stretching }\end{array}$ & $\begin{array}{r}6.0 \\
\pm 1.4\end{array}$ & $\begin{array}{r}5.0 \\
\pm 1.3\end{array}$ & $\begin{array}{r}2.9 \\
\pm 1.2\end{array}$ & $\begin{array}{r}1.2 \\
\pm 0.4\end{array}$ & $\begin{array}{r}247.5 \\
\pm 62.0\end{array}$ & $\begin{array}{l}229.6 \\
\pm 62.8\end{array}$ & $\begin{array}{r}244.3 \\
\pm 53.1\end{array}$ & $\begin{array}{l}263.1 \\
\pm 61.9\end{array}$ & $\begin{array}{r}207.6 \\
\pm 40.2\end{array}$ & $\begin{array}{r}196.4 \\
\pm 46.2\end{array}$ & $\begin{array}{l}209.5 \\
\pm 47.0\end{array}$ & $\begin{array}{l}222.3 \\
\pm 47.9\end{array}$ \\
\hline $\begin{array}{l}\text { High-Intensity } \\
\text { Passive Static } \\
\text { Stretching }\end{array}$ & $\begin{array}{r}5.9 \\
\pm 1.8\end{array}$ & $\begin{array}{r}5.7 \\
\pm 2.2\end{array}$ & $\begin{array}{r}3.7 \\
\pm 1.4\end{array}$ & $\begin{array}{r}2.4 \\
\pm 1.3\end{array}$ & $\begin{array}{l}218.2 \\
\pm 59.7\end{array}$ & $\begin{array}{r}173.4 \\
\pm 35.6\end{array}$ & $\begin{array}{r}208.0 \\
\pm 44.7\end{array}$ & $\begin{array}{r}195.9 \\
\pm 31.9\end{array}$ & $\begin{array}{r}181.3 \\
\pm 41.2\end{array}$ & $\begin{array}{r}163.5 \\
\pm 41.7\end{array}$ & $\begin{array}{r}172.7 \\
\pm 50.1\end{array}$ & $\begin{array}{r}186.6 \\
\pm 39.1\end{array}$ \\
\hline Control & $\begin{array}{r}5.9 \\
\pm 1.8\end{array}$ & $\begin{array}{r}5.7 \\
\pm 1.9\end{array}$ & $\begin{array}{r}4.0 \\
\pm 1.3\end{array}$ & $\begin{array}{r}2.2 \\
\pm 1.3\end{array}$ & $\begin{array}{r}214.8 \\
\pm 52.7\end{array}$ & $\begin{array}{r}196.2 \\
\pm 49.8\end{array}$ & $\begin{array}{r}179.4 \\
\pm 42.8\end{array}$ & $\begin{array}{l}200.6 \\
\pm 65.6\end{array}$ & $\begin{array}{r}185.1 \\
\pm 55.2\end{array}$ & $\begin{array}{r}165.1 \\
\pm 49.5\end{array}$ & $\begin{array}{r}169.6 \\
\pm 50.6\end{array}$ & $\begin{array}{r}172.8 \\
\pm 55.4\end{array}$ \\
\hline
\end{tabular}


TABLE 2. Changes in perceived muscle soreness, creatine kinase, high sensitivity C-reactive protein (hsCRP), eccentric peak torque and isometric peak torque in the low-intensity passive static stretching (LIS) group versus high-intensity passive static stretching (HIS) group ( $n=10$ per group). (Analyses were adjusted to baseline grand means for each outcome)

\begin{tabular}{|c|c|c|c|c|c|c|}
\hline Outcomes & Time & $\begin{array}{c}\text { LIS \% } \\
\text { change, } \\
\text { MD } \pm \text { SD }\end{array}$ & $\begin{array}{c}\text { HIS \% } \\
\text { change, } \\
\pm \text { SD }\end{array}$ & $\begin{array}{l}\text { LIS vs HIS \% } \\
\text { change, } \\
\text { MD }[90 \% \mathrm{CI}]\end{array}$ & $\begin{array}{l}\text { LIS vs HIS effects, } \\
\qquad d[90 \% \mathrm{CI}]\end{array}$ & Qualitative inference \\
\hline & $0-24 h^{*}$ & $-18.3 \pm 30.1$ & $-6.7 \pm 37.7$ & $-12.4[-30.4,10.2]$ & $-0.27[-0.74,0.20]$ & Possibly beneficial (60\%) \\
\hline \multirow{3}{*}{$\begin{array}{l}\text { Perceived } \\
\text { Muscle } \\
\text { Soreness }\end{array}$} & $24-48 h$ & $-44.3 \pm 63.6$ & $-32.8 \pm 60.3$ & $-17.2[-43.2,20.8]$ & $-0.39[-1.15,0.39]$ & Unclear \\
\hline & $48-72 h$ & $-56.7 \pm 73.0$ & $-37.1 \pm 46.4$ & $-31.1[-52.5,-0.1]$ & $-0.76[-1.52,0.00]$ & Likely beneficial (89\%) \\
\hline & $0-72 h$ & $-80.3 \pm 35.6$ & $-60.6 \pm 60.7$ & $-50.0[-63.6,-31.5]$ & $-1.41[-2.06,-0.77]$ & Most likely beneficial (100\%) \\
\hline \multirow{3}{*}{$\begin{array}{l}\text { Eccentric } \\
\text { Peak } \\
\text { Torque } \\
(\mathrm{Nm})\end{array}$} & Pre-24h & $-7.1 \pm 12.4$ & $-23.5 \pm 20.3$ & $21.5[7.0,37.8]$ & $0.71[0.25,1.16]$ & Very likely beneficial (96\%) \\
\hline & Pre-48h & $1.4 \pm 12.4$ & $-6.1 \pm 17.7$ & $8.0[-3.7,21.2]$ & $0.28[-0.14,0.70]$ & Possibly beneficial (63\%) \\
\hline & Pre-72h & $7.7 \pm 10.0$ & $-12.8 \pm 15.4$ & $23.4[11.8,36.3]$ & $0.76[0.40,1.12]$ & Very likely beneficial (99\%) \\
\hline \multirow{3}{*}{$\begin{array}{l}\text { Isometric } \\
\text { Peak } \\
\text { Torque } \\
(\mathrm{Nm})\end{array}$} & Pre-24h & $-7.1 \pm 8.0$ & $-10.4 \pm 13.4$ & $3.6[-5.0,13.0]$ & $0.14[-0.20,0.48]$ & Possibly trivial (57\%) \\
\hline & Pre-48h & $0.4 \pm 13.6$ & $-5.2 \pm 15.1$ & $5.9[-5.2,18.3]$ & $0.23[-0.21,0.66]$ & Possibly beneficial (54\%) \\
\hline & Pre-72h & $7.0 \pm 10.4$ & $-17.5 \pm 145.1$ & $29.8[-25.8,127.2]$ & $1.03[-1.18,3.24]$ & Unclear \\
\hline \multirow{3}{*}{$\begin{array}{l}\text { Creatine } \\
\text { Kinase } \\
(\mathrm{U} / \mathrm{L})\end{array}$} & Pre-24h & $68.0 \pm 155.2$ & $54.9 \pm 77.5$ & $8.4[-42.5,104.3]$ & $0.10[-0.71,0.92]$ & Unclear \\
\hline & Pre-48h & $50.3 \pm 57.1$ & $54.5 \pm 89.9$ & $-2.7[-38.2,53.2]$ & $-0.04[-0.62,0.55]$ & Unclear \\
\hline & Pre-72h & $13.8 \pm 33.2$ & $39.3 \pm 54.1$ & $-18.3[-39.6,10.6]$ & $-0.26[-0.65,0.13]$ & Possibly beneficial (61\%) \\
\hline \multirow{3}{*}{$\begin{array}{l}\text { hsCRP } \\
\text { (mg/L) }\end{array}$} & Pre-24h & $15.6 \pm 42.7$ & $-18.5 \pm 29.6$ & $41.7[10.9,81.3]$ & $0.35[0.10,0.60]$ & Likely harmful (85\%) \\
\hline & Pre-48h & $-9.0 \pm 55.7$ & $-25.6 \pm 110.5$ & $22.3[-24.7,98.6]$ & $0.20[-0.29,0.69]$ & Unclear \\
\hline & Pre-72h & $-25.7 \pm 55.3$ & $-24.5 \pm 65.5$ & $-1.6[-32.1,42.6]$ & $-0.02[-0.39,0.36]$ & Unclear \\
\hline
\end{tabular}

Key: $\mathrm{MD}=$ mean difference; $\mathrm{SD}=$ standard deviation (presented as a CV \%); $90 \% \mathrm{Cl}=90 \%$ confidence interval; $d=\mathrm{Cohen}$ 's $d$ effect size

${ }^{*} 0-24 \mathrm{~h}=$ pre-unaccustomed eccentric exercise to $24 \mathrm{~h}$ post-unaccustomed eccentric exercise 
TABLE 3. Changes in perceived muscle soreness, creatine kinase, high sensitivity C-reactive protein (hsCRP), eccentric peak torque and isometric peak torque in the low-intensity passive static stretching (LIS) group versus control (CON) group ( $\mathrm{n}=10$ per group). (Analyses were adjusted to baseline grand means for each outcome)

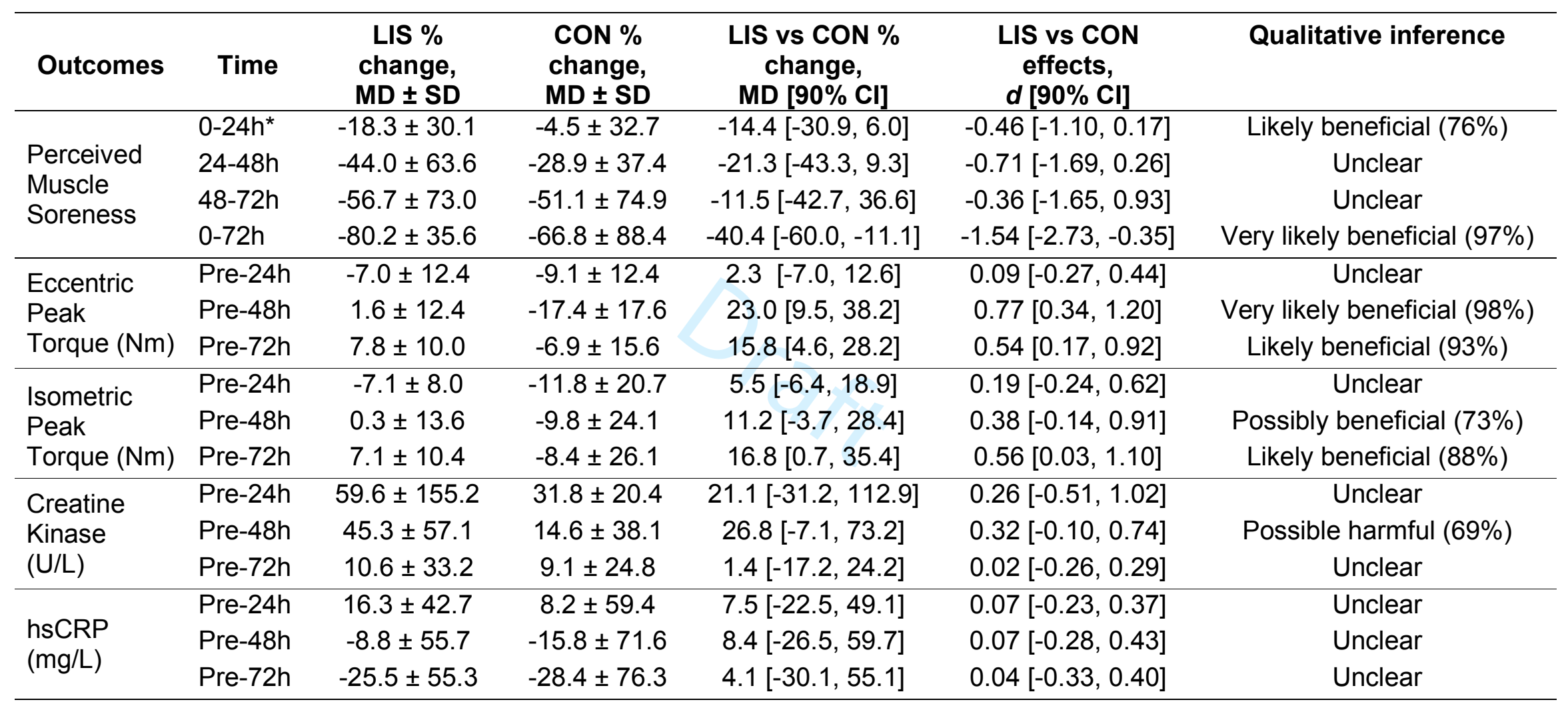

Key: MD = mean difference; SD = standard deviation (presented as a CV \%); $90 \% \mathrm{Cl}=90 \%$ confidence interval; $d=\mathrm{Cohen}$ 's $d$ effect size

* $0-24 \mathrm{~h}=$ pre-unaccustomed eccentric exercise to $24 \mathrm{~h}$ post-unaccustomed eccentric exercise 
TABLE 4. Changes in perceived muscle soreness, creatine kinase, high sensitivity C-reactive protein (hsCRP), eccentric peak torque and isometric peak torque in the high-intensity passive static stretching (HIS) group versus control $(\mathrm{CON})$ group ( $\mathrm{n}=10$ per group). (Analyses were adjusted to baseline grand means for each outcome)

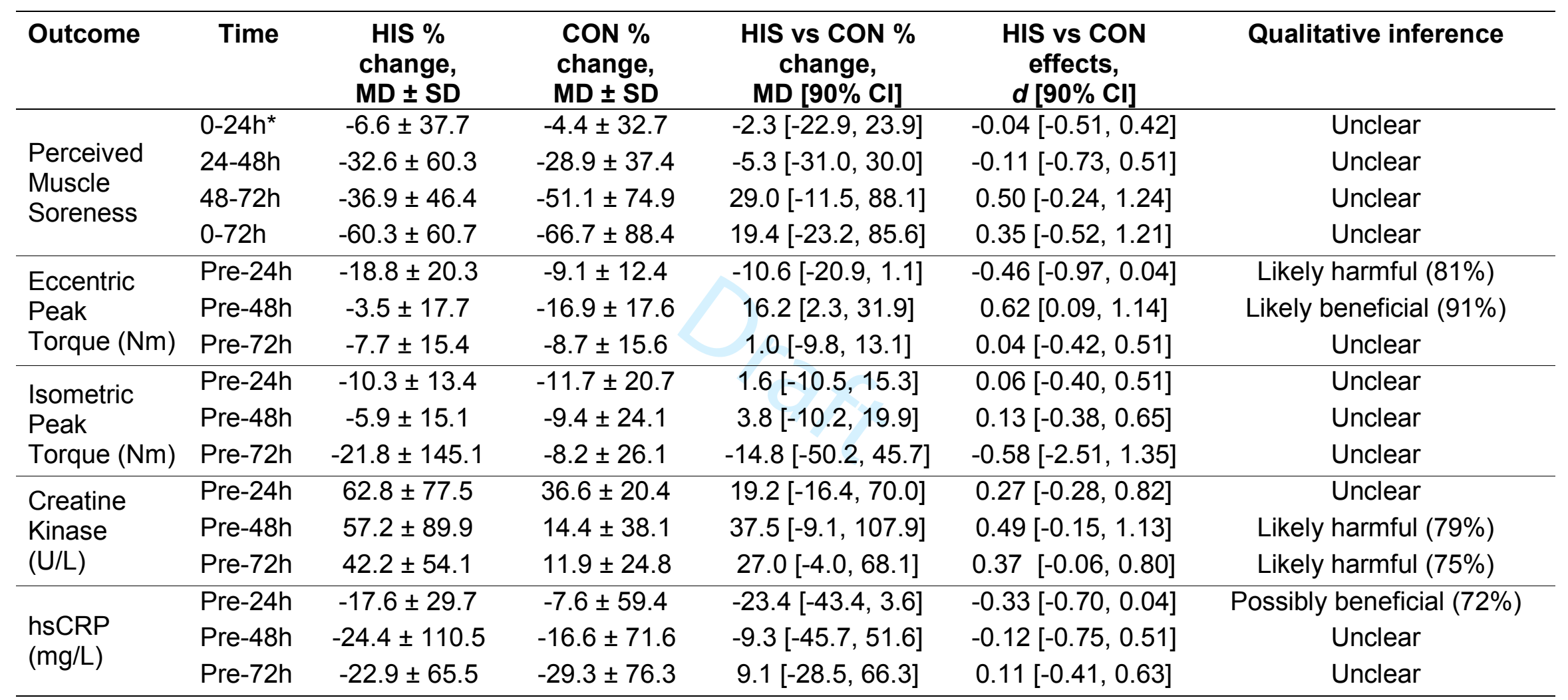

Key: MD = mean difference; SD = standard deviation (presented as a CV \%); $90 \% \mathrm{Cl}=90 \%$ confidence interval; $d=\mathrm{Cohen}$ 's $d$ effect size

${ }^{*} 0-24 \mathrm{~h}=$ pre-unaccustomed eccentric exercise to $24 \mathrm{~h}$ post-unaccustomed eccentric exercise 
TABLE 5 - Soreness, Creatine Kinase and High Sensitivity C - reactive protein over 72 hours Post Unaccustomed Eccentric Exercise Protocol (Values are Mean $\pm S D ; n=10$ per group).

\begin{tabular}{|c|c|c|c|c|c|c|c|c|}
\hline \multirow{2}{*}{ Condition } & \multicolumn{4}{|c|}{ Creatine Kinase (U/L) } & \multicolumn{4}{|c|}{$\begin{array}{l}\text { High Sensitivity C-Reactive Protein } \\
\qquad(\mathrm{mg} / \mathrm{L})\end{array}$} \\
\hline & Oh & $24 h$ & $48 h$ & $72 \mathrm{~h}$ & Oh & $24 \mathrm{~h}$ & $48 \mathrm{~h}$ & $72 \mathrm{~h}$ \\
\hline $\begin{array}{l}\text { Low Intensity } \\
\text { Passive Static } \\
\text { Stretching }\end{array}$ & $\begin{array}{r}316.5 \\
\pm 271.4\end{array}$ & $\begin{array}{r}613.5 \\
\pm 442.9\end{array}$ & $\begin{array}{r}440.5 \\
\pm 311.8\end{array}$ & $\begin{array}{r}324.5 \\
\pm 198.9\end{array}$ & $\begin{array}{r}1.73 \\
\pm 1.66\end{array}$ & $\begin{array}{r}1.93 \\
\pm 2.08\end{array}$ & $\begin{array}{r}1.63 \\
\pm 1.74\end{array}$ & $\begin{array}{r}1.32 \\
\pm 1.57\end{array}$ \\
\hline $\begin{array}{l}\text { High Intensity } \\
\text { Passive Static } \\
\text { Stretching }\end{array}$ & $\begin{array}{r}239.4 \\
\pm 183.6\end{array}$ & $\begin{aligned} & 378.43 \\
\pm & 243.1\end{aligned}$ & $\begin{array}{r}408.3 \\
+391.16\end{array}$ & $\begin{array}{r}336.3 \\
\pm 277.7\end{array}$ & $\begin{array}{r}1.78 \\
\pm 1.35\end{array}$ & $\begin{array}{r}1.34 \\
\pm 0.77\end{array}$ & $\begin{array}{r}1.37 \\
\pm 1.04\end{array}$ & $\begin{array}{r}1.68 \\
\pm 1.19\end{array}$ \\
\hline Control & $\begin{array}{r}297.9 \\
\pm 187.1\end{array}$ & $\begin{array}{r}380.9 \\
+215.6\end{array}$ & $\begin{array}{r}362.5 \\
\pm 311.6\end{array}$ & $\begin{array}{r}320.6 \\
+208.3\end{array}$ & $\begin{array}{r}1.58 \\
\pm 1.29\end{array}$ & $\begin{array}{r}1.60 \\
\pm 1.29\end{array}$ & $\begin{array}{r}1.23 \\
\pm 0.90\end{array}$ & $\begin{array}{r}1.02 \\
\pm 0.77\end{array}$ \\
\hline
\end{tabular}




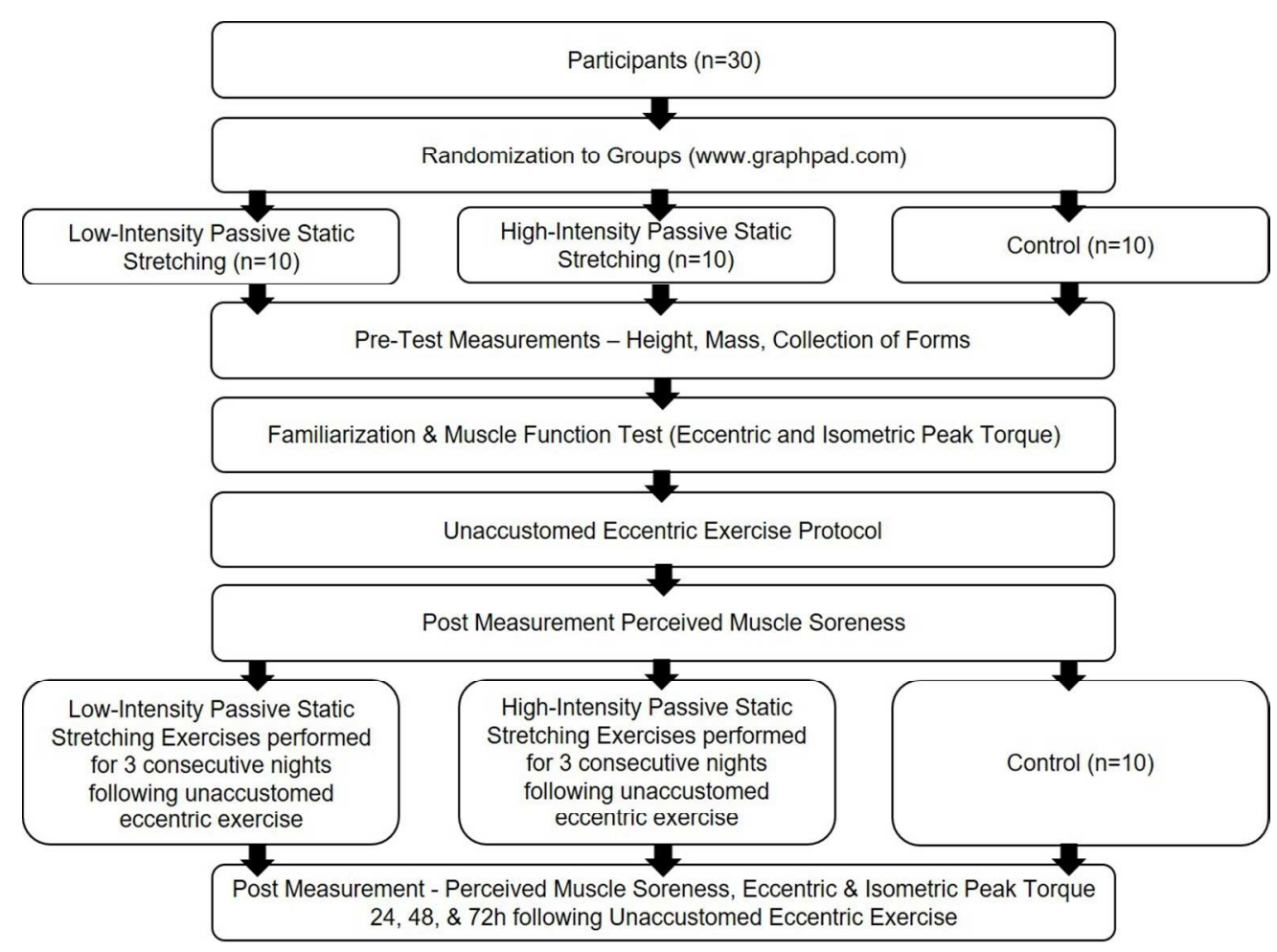

FIGURE 1 - Methodology Schematic for Experimental Process

$210 \times 156 \mathrm{~mm}(150 \times 150 \mathrm{DPI})$ 

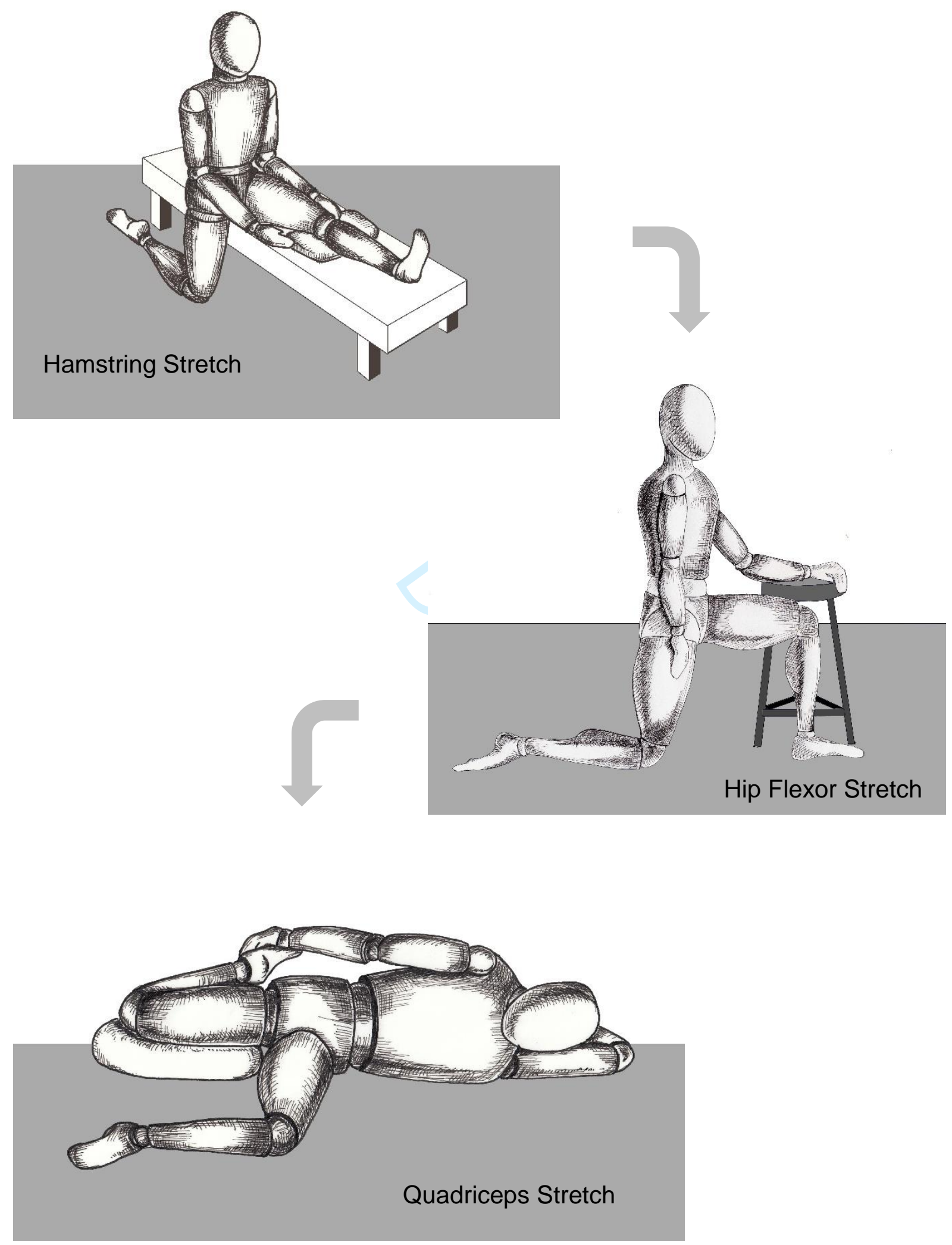

FIGURE 2 - Passive Static Stretching Exercises 


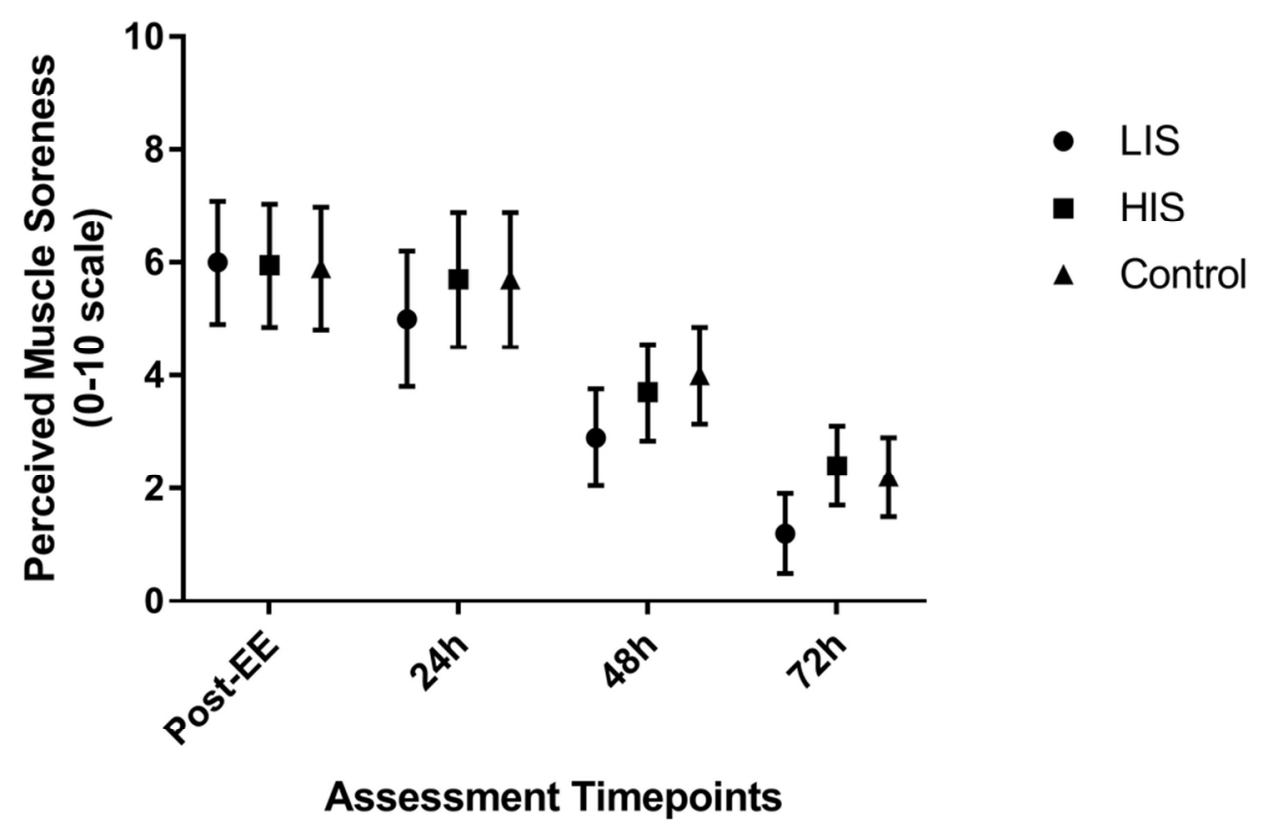

FIGURE 3 - Perceived Muscle Soreness (raw) $91 \times 62 \mathrm{~mm}(300 \times 300$ DPI $)$ 


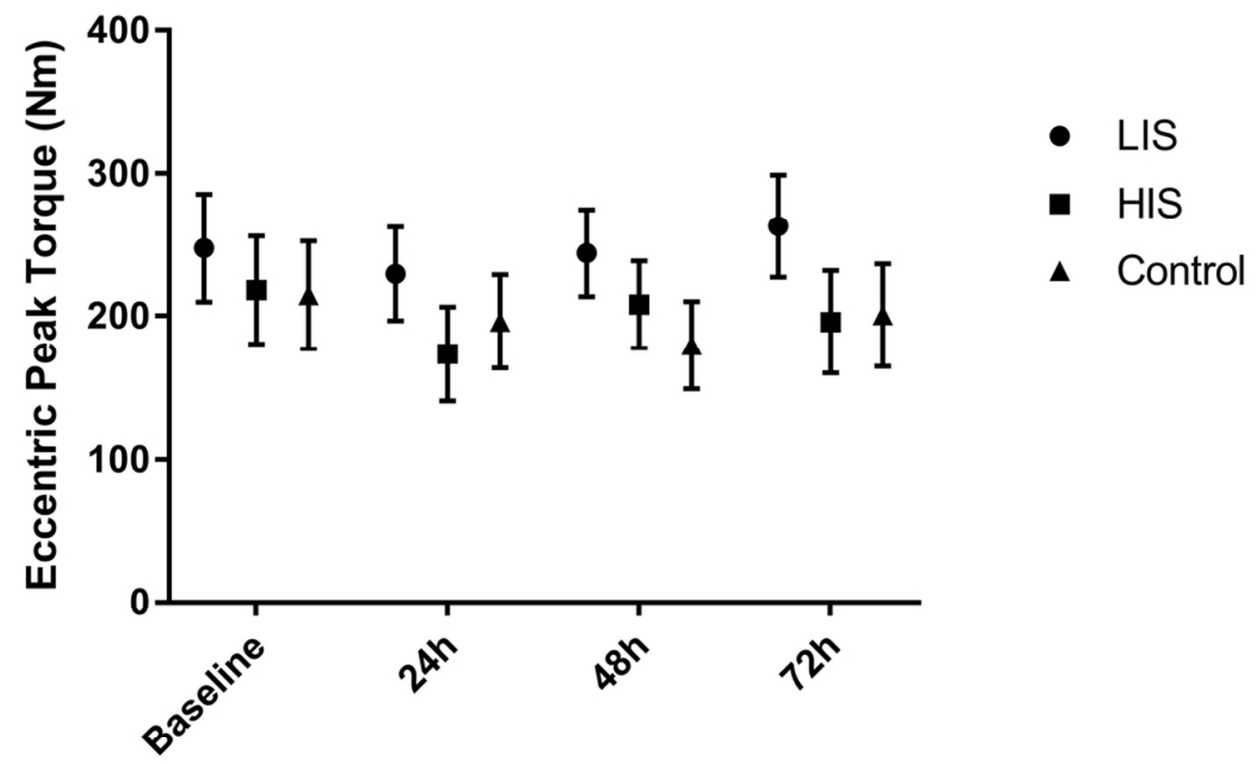

Assessment Timepoints

FIGURE 4 - Eccentric Peak Torque (raw)

$92 \times 64 \mathrm{~mm}(300 \times 300$ DPI $)$ 


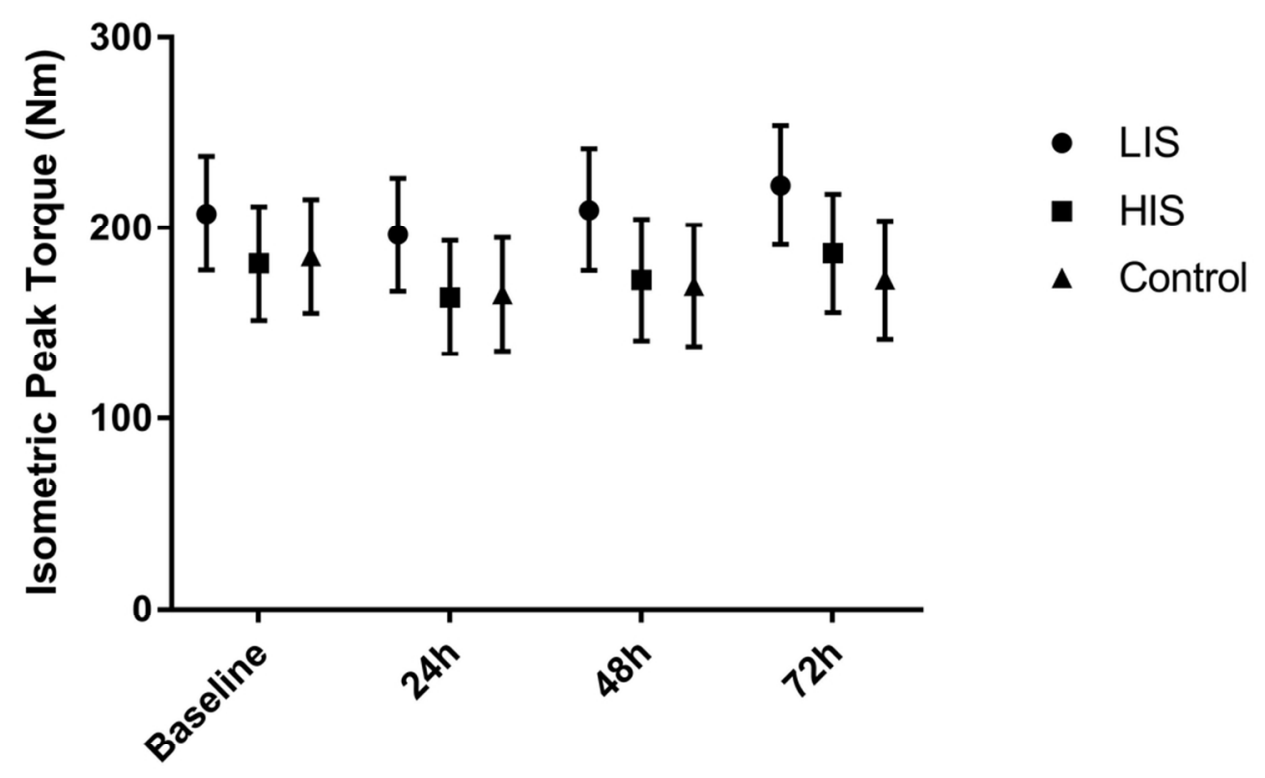

\section{Assessment Timepoints}

FIGURE 5 - Isometric Peak Torque (raw) $92 \times 64 \mathrm{~mm}(300 \times 300 \mathrm{DPI})$ 


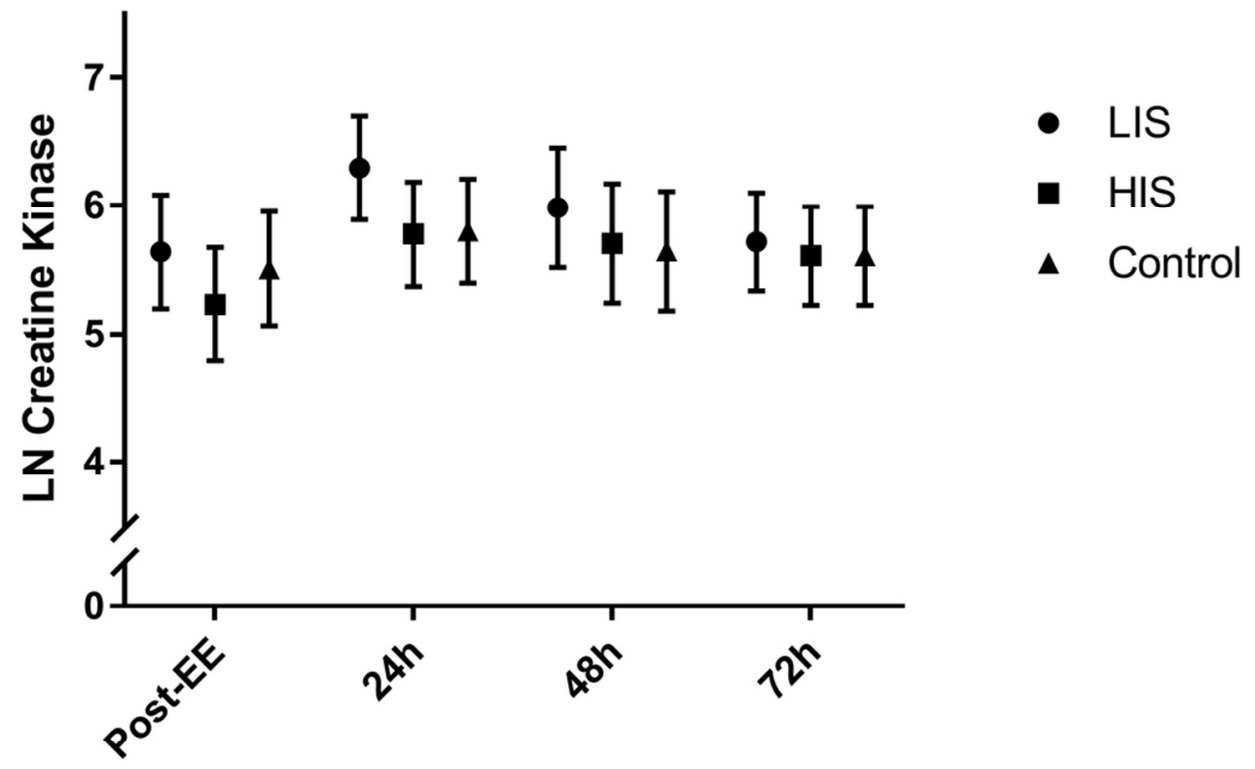

\section{Assessment Timepoints}

FIGURE 6 - Creatine Kinase (LN transformed)

$91 \times 65 \mathrm{~mm}(300 \times 300$ DPI $)$ 


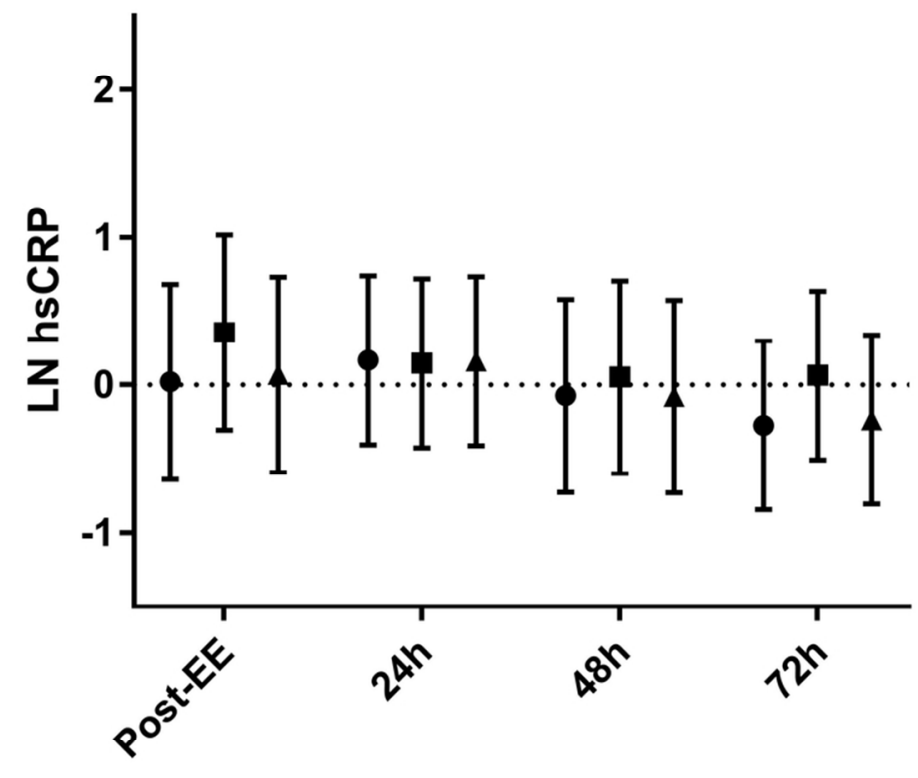

- LIS

- HIS

- Control

Assessment Timepoints

FIGURE 7 - hsCRP (LN transformed)

$91 \times 65 \mathrm{~mm}(300 \times 300 \mathrm{DPI})$ 
FIGURE CAPTIONS FOR MANUSCRIPT

The Effects of Different Passive Static Stretching Intensities on Recovery from Unaccustomed Eccentric Exercise - A Randomized Controlled Trial

FIGURE 1 - Methodology Schematic of Experimental Process

FIGURE 2 - Passive Static Stretching Exercises

FIGURE 3 - Perceived Muscle Soreness (raw)

FIGURE 4 - Eccentric Peak Torque (raw)

FIGURE 5 - Isometric Peak Torque (raw)

FIGURE 6 - Creatine Kinase (LN transformed)

FIGURE 7 - hsCRP (LN transformed) 